\section{DNA profiling and the police}

SIR - Peter Aldhous reports (Nature 355, 191; 16 January 1992) that the civil rights group Liberty is seeking to take London's Metropolitan Police to the European Court of Human Rights, questioning the legality of our database of DNA profiling results. While I take a positive view of Liberty's attempts to clarify the law, it may have chosen a case that does not serve its purpose well.

Contrary to the account in Nature, the DNA profile of Roy Williams (a man questioned during a 1988 murder inquiry and subsequently cleared after voluntarily submitting a DNA sample for analysis) has never been on our DNA database. The Metropolitan Police Forensic Science Laboratory (MPFSL) did not measure the DNA profile in question. (This was done before we had brought DNA profiling into operational use.) We were simply told by the commercial company that did the work that Williams' DNA profile did not match with our scene-of-crime sample.

The MPFSL has not sought to hide its DNA database. I have lectured on it at the Royal Society and in the House of Commons; we show it (without breaching confidentiality) to most of our visitors, and have described both the database and its contents in our submission to the Royal Commission on Criminal Justice.

The DNA results held in our database are those from unsolved cases, from convicted criminals and from those awaiting trial in cases for which they provided a comparison blood sample. The House of Commons Home Affairs Committee wants the scope to be greatly expanded, but this would require new legislation. Many people believe that DNA profiles should be recorded for anyone convicted of a crime of violence, or at least for all sex offenders. The MFPSL view is that this is for the public to debate and for parliament to decide. In the meantime we work within the law as we understand it.

For example, if we obtain the DNA profile of someone convicted of rape before the technique became available, but who happens to be cleared in the case for which he donated the DNA sample, we do not put his DNA information into the database. We simply retain the X-ray film and the normal entries in our laboratory notebooks. Even here there are difficulties. We may be criticized for not tearing up our notebooks when suspects are cleared by our work. But imagine the outcry if forensic science laboratories did start destroying entries in laboratory notebooks! Public laboratories should not have to work under conditions of such legal ambiguity. The public desire for confidence in its criminal justice system points to a need for some of these areas of uncertainty to be sorted out.

In conclusion, I should like to mention that among all the troubles that have hit forensic science in recent times, the MFSPL has never been implicated - in spite of being the largest forensic science laboratory in Europe, with an annual caseload of about 17,000 cases. And, far from muddying the waters on DNA profiling, it was my personal initiative that brought an agreement on a standard DNA technology choice in Europe, without which national databases would not be possible. The MPFSL also offered to run its DNA database on behalf of the nation before any alternative was available.

The Metropolitan Police is contrite in one respect. Roy Williams was apparently not told immediately that he had been cleared when we passed that information on to the investigating officers. I should like to add my own apologies as a Metropolitan Police employee to the others that have been given in the past.

BRIAN SHEARD

(Director)

Metropolitan Police

Forensic Science Laboratory,

109 Lambeth Road,

London SE1 7LP, UK

\section{IQ and diet}

SIR - I should like to correct an impression created by your News story "IQ pills' land in trouble" (Nature 355, 285 ; 1992). The charges brought by trading standards officers refer to advertising claims. The Benton and Roberts paper (The Lancet i, 140); 1988) was careful to make no claims: having reported the finding that a vitamin/mineral supplement increased the nonverbal intelligence of a group of school children, it concluded that "the study must now be replicated, and ... the underlying mechanism must be established".

I have recently published a study that reports increased intelligence scores when six-year-olds receive supplements (Benton and Cook Personality and Individual Differences, 12, 1151-1158; 1991). There are so far five studies that report positive findings in at least some of their sample. That two studies have reported negative findings can be explained easily by the obvious assumption that only some children respond, those with a poor diet.

Department of Psychology,

University College,

Swansea SA2 8PP, UK

\section{Gene therapy}

SIR - I have no doubt about the enthusiasm of scientists at the US National Institutes of Health (NIH) for the future of gene therapy, but from Nature I expect a more critical evaluation than that in "Gene therapy on the move" (354, 429; 1991).

For example, NIH and corporate researchers may be able to avoid issues of prenatal use of DNA technology as a method of disease control through reproductive choice; or eschew epidemiological conclusions that methods of disease prevention are already mostly at hand in the form of behavioural and environmental change; or pretend that polygenic diseases such as cancer, heart and liver diseases are likely new targets of gene therapy; or confuse arteriosclerosis prevention by neonatal transfection of LDL genes - which will predictably affect fewer than 1 per cent of those afflicted with artery diseases - with prevention for large majorities by change in life habits; but your reporter should not fail to remind us of these oversights and simplifications.

And the quotation from the child with cystic fibrosis surely belonged to a charity 'telethon'. Nature reporters and NIH institute directors should all be required to have read Thomas McKeown's last book, The Origins of Human Disease (Blackwell, 1988), as background support against the ever-increasing hype from our biomedical establishment leaders who, recognizing that current gene therapy addresses less than 2 per cent of the total disease problem (monogenic diseases) in the Western world, are busy reconstructing disease aetiology altogether.

RICHARD C. STROHMAN Department of Molecular \& Cell Biology, University of California,

Berkeley, California 94720, USA

\section{Old argument}

SIR - Zakaria Erzinclioglu (Nature 355, $195 ; 1992)$ considers it absurd that we refer to things or people as "ancient" or "old" rather than "early" or "young" when they happened or live a long time ago, for example, are trilobites ancient or merely early? Is Aristotle?

From our point of view which is generally the coordinate system we favour, trilobites and Aristotle are both; they were here early (earlier than we were), younger than we are, but from our habitual standpoint of looking back through time from where we happen to be at the moment, they are ancient and therefore older than we are.

RALPH ESTLING

The Old Parsonage, Dowlish Wake, IIminster, Somerset TA19 ONY, UK 